\title{
The direct effect of aerosols on solar radiation based on satellite observations, reanalysis datasets, and spectral aerosol optical properties from Global Aerosol Data Set (GADS)
}

\author{
N. Hatzianastassiou ${ }^{1,2}$, C. Matsoukas ${ }^{2,3}$, E. Drakakis ${ }^{2,5}$, P. W. Stackhouse Jr. ${ }^{6}$, P. Koepke ${ }^{7}$, A. Fotiadi ${ }^{2,4}$, \\ K. G. Pavlakis ${ }^{2,8}$, and I. Vardavas ${ }^{2,4}$ \\ ${ }^{1}$ Laboratory of Meteorology, Department of Physics, University of Ioannina, 45110 Ioannina, Greece \\ ${ }^{2}$ Foundation for Research and Technology-Hellas, Heraklion, Crete, Greece \\ ${ }^{3}$ Department of Environment, University of the Aegean, Mytilene, Greece \\ ${ }^{4}$ Department of Physics, University of Crete, Crete, Greece \\ ${ }^{5}$ Department of Electrical Engineering, Technological Educational Institute of Crete, Heraklion, Greece \\ ${ }^{6}$ Atmospheric Sciences, NASA Langley Research Center, Hampton, Virginia, USA \\ ${ }^{7}$ Meteorological Institute, University of Munich, Munich, Germany \\ ${ }^{8}$ Department of General Applied Science, Technological Educational Institute of Crete, Heraklion, Greece
}

Received: 16 November 2006 - Published in Atmos. Chem. Phys. Discuss.: 18 January 2007

Revised: 5 April 2007 - Accepted: 28 April 2007 - Published: 16 May 2007

\begin{abstract}
A global estimate of the seasonal direct radiative effect (DRE) of natural plus anthropogenic aerosols on solar radiation under all-sky conditions is obtained by combining satellite measurements and reanalysis data with a spectral radiative transfer model and spectral aerosol optical properties taken from the Global Aerosol Data Set (GADS). The estimates are obtained with detailed spectral model computations separating the ultraviolet (UV), visible and near-infrared wavelengths. The global distribution of spectral aerosol optical properties was taken from GADS whereas data for clouds, water vapour, ozone, carbon dioxide, methane and surface albedo were taken from various satellite and reanalysis datasets. Using these aerosol properties and other related variables, we generate climatological (for the 12-year period 1984-1995) monthly mean aerosol DREs. The global annual mean DRE on the outgoing SW radiation at the top of atmosphere (TOA, $\Delta F_{\mathrm{TOA}}$ ) is $-1.62 \mathrm{~W} \mathrm{~m}^{-2}$ (with a range of -15 to $10 \mathrm{~W} \mathrm{~m}^{-2}$, negative values corresponding to planetary cooling), the effect on the atmospheric absorption of SW radiation $\left(\Delta F_{\mathrm{atmab}}\right)$ is $1.6 \mathrm{~W} \mathrm{~m}^{-2}$ (values up to $35 \mathrm{~W} \mathrm{~m}^{-2}$, corresponding to atmospheric warming), and the effect on the surface downward and absorbed SW radiation ( $\Delta F_{\text {surf }}$, and $\Delta F_{\text {surfnet }}$, respectively) is -3.93 and $-3.22 \mathrm{~W} \mathrm{~m}^{-2}$ (values up to -45 and $-35 \mathrm{~W} \mathrm{~m}^{-2}$, respectively, corresponding to surface cooling). According to our results, aerosols decrease/increase the plan-
\end{abstract}

Correspondence to: N. Hatzianastassiou

(nhatzian@cc.uoi.gr) etary albedo by -3 to $13 \%$ at the local scale, whereas on planetary scale the result is an increase of $1.5 \%$. Aerosols can warm locally the atmosphere by up to $0.98 \mathrm{~K} \mathrm{day}^{-1}$, whereas they can cool the Earth's surface by up to $-2.9 \mathrm{~K} \mathrm{day}^{-1}$. Both these effects, which can significantly modify atmospheric dynamics and the hydrological cycle, can produce significant planetary cooling on a regional scale, although planetary warming can arise over highly reflecting surfaces. The aerosol DRE at the Earth's surface compared to TOA can be up to 15 times larger at the local scale. The largest aerosol DRE takes place in the northern hemisphere both at the surface and the atmosphere, arising mainly at ultraviolet and visible wavelengths.

\section{Introduction}

Atmospheric aerosols, both natural and anthropogenic, can cause climate change through their direct, indirect and semidirect effects on the radiative energy budget of the Earthatmosphere system. The effect of anthropogenic aerosols only, on a global average, is likely to be comparable in magnitude to the radiative forcing of about $2.4 \mathrm{~W} \mathrm{~m}^{-2}$ by anthropogenic greenhouse gases (IPCC, 2001). However, the quantification of the aerosol effects is more complex than the quantification of radiative forcing by greenhouse gases because aerosol mass and particle number concentrations are highly variable in space and time, due to their much shorter

Published by Copernicus Publications on behalf of the European Geosciences Union. 
atmospheric lifetime compared with the important greenhouse gases. Aerosol properties are difficult to measure without instrumental offsets or bias, making it difficult to estimate the aerosol radiative effects. Therefore, there is large uncertainty regarding the aerosol overall radiative forcing (Remer and Kaufman, 2006; Granger Morgan et al., 2006; Yu et al., 2006). Better estimates of the aerosol radiative effects on a planetary scale are required to reduce the uncertainties.

The present study focuses on the direct radiative effect (DRE) of aerosols, which is the overall effect of natural plus anthropogenic aerosols on the radiative energy budget, and it is different to the direct climate forcing (DCF) which represents the corresponding effect of anthropogenic aerosols only. Although the present consensus is that the DRE is better known than the indirect and semi-direct effects, there is still a large degree of uncertainty. Our study deals with the direct effect of aerosols on the shortwave (SW) radiation budget, since the main DRE lies at these wavelengths, being much smaller in the longwave (thermal infrared). Even for dust, the thermal infrared radiative effects are about $10 \%$ those for the shortwave radiation (Tanré et al., 2003).

The assessments of aerosol DRE fall into three broad categories: (i) measurement-based (e.g. Bellouin et al., 2005; Loeb and Manalo-Smith, 2005; Zhang et al., 2005; Remer and Kaufman, 2006; Christopher et al., 2006), (ii) modelbased (e.g. Jacobson, 2001; Chin et al., 2001; Liao et al., 2004; Koch and Hansen, 2005; Reddy et al., 2005; Takemura et al., 2005), and (iii) measurement-model integrated (e.g. Chu et al., 2002; Yu et al., 2004; Chung et al., 2005). Measurements involve in-situ, satellite and suborbital remote sensing data. Yu et al. (2006) provide a review of the above assessments. Each method has advantages and drawbacks. For example, there is a wide range of discrepancy in model results because of the many inherent assumptions involved in modelling the aerosol effect on climate (Schulz et al., 2006), so there are difficulties in reproducing correctly satellite observations (Bellouin et al., 2005; Zhao et al., 2005). On the other hand, although many problems related to satellite observations of aerosols have been resolved by more sophisticated instruments, there are still problems as shown by discrepancies between different satellite products (Zhao et al., 2005).

The present study takes an alternate approach using quality available global observational data and detailed spectral radiative transfer flux calculations performed with a radiative transfer model. The adopted technique relies on spectral aerosol optical properties from the Global Aerosol Data Set (GADS, Koepke et al., 1997) and satellite observations for the key surface and atmospheric parameters such as clouds, water vapour, surface albedo and ozone taken from comprehensive global climatological databases (NASA Langley Research Center data set, International Satellite Cloud Climatology Project, ISCCP, Goddard Earth Observing System, GEOS, version 1 reanalysis, provided by the Data Assimilation Office, DAO, of NASA's Goddard Space Flight Cen- ter, GSFC). This study incorporates realistic surface and atmospheric conditions, especially those of clouds, to reduce some of the major sources of error in estimates of the direct forcing/effect (Podgorny and Ramanathan, 2001; Chung et al., 2005). In addition, an important improvement in this study, compared to other studies, is that the aerosol DRE is computed at a very high spectral resolution, while other radiation transfer, general circulation (GCM) and chemical transport (CTM) models, usually include a few spectral bands in the whole SW range. This is achieved only in few other studies, such as in that by Jacobson (2001) where 153 wavelengths in the SW range are considered, 86 of them lying in the UV and visible and 67 in the near-IR. This can be critical, since inadequate treatment of spectrally resolved aerosol properties can result in modified aerosol forcings of up to $16 \%$ on a global scale, and $100 \%$ locally (Hatzianastassiou et al., 2004b). Recently, Redemann et al. (2006) have shown that ratios of aerosol radiative forcing at 400 and $1600 \mathrm{~nm}$ can be as high as a factor of 10, depending on the aerosol type. Our DRE computations refer to the whole solar spectrum $(0.2-10 \mu \mathrm{m})$, and they are performed at 117 wavelengths ranging from 0.2 to $1.0 \mu \mathrm{m}$, and 10 spectral intervals in the range $1.0-10.0 \mu \mathrm{m}$ (note that our study deals only with solar radiation). The inclusion of near-IR has been shown (e.g. Bush and Valero, 2003; Nishizawa et al., 2004; Zhou et al., 2005; Hatzianastassiou et al., 2006) to be essential for accurately computing the aerosol radiative effects. We have used a detailed spectral radiative transfer model using as input data the detailed spectral aerosol optical properties (extinction optical thickness, AOT, single scattering albedo, $\omega_{\text {aer }}$, and asymmetry parameter, $g_{\text {aer }}$ ) from GADS, given at 40 wavelengths within the range 0.2 to $10.0 \mu \mathrm{m}$, using interpolation.

Following this approach, we produced global DRE monthly climatologies for the 12-year period 1984-1995 for both clear and all-sky conditions, for winter and summer. The DRE is computed at TOA, in the atmosphere and at the Earth's surface. All computations were performed at a geographical cell level of $1^{\circ} \times 1^{\circ}$ latitude-longitude on a daily basis, and subsequently averaged and presented as monthly means. Our results provide a realistic climatological assessment of aerosol SW DRE.

This study complements the works by Hatzianastassiou et al. (2004a, 2006). In Hatzianastassiou et al. (2004a) the global distribution of aerosol DRE in the ultraviolet and visible wavelengths was computed for clear-sky conditions, for the 12-year period 1984-1995. Recently, Hatzianastassiou et al. (2006) calculated the aerosol DRE in the solar nearinfrared (IR) for both clear- and all-sky conditions for the period 1984-1995. The present study is an integration of the previous two studies, providing estimates of clear- and allsky DREs for the total SW range for the period 1984-1995.

The methodology, and descriptions of the radiative transfer model and the climatological input data were given in detail in Hatzianastassiou et al. (2004a, 2006), so only a very 
brief description of these will be given in Sect. 2. More emphasis will be given to the results (Sect. 3), before the conclusions (Sect. 4).

\section{Model and input data}

The radiative transfer model and the various assimilated input data are briefly described in this section. For more details the reader is referred to the relevant studies by Hatzianastassiou et al. (2004a, b) and Hatzianastassiou et al. (2006).

\subsection{The radiative transfer model}

The deterministic spectral radiative transfer model used here was developed from a radiative-convective model (Vardavas and Carver, 1984). The incoming solar irradiance at TOA is computed for the spectral interval $0.2-10.0 \mu \mathrm{m}$, based on the spectral profile of Thekaekara and Drummond (1971), using a solar constant $S_{o}=1367 \mathrm{~W} \mathrm{~m}^{-2}$ (e.g. Willson, 1997) corrected for the Earth's elliptical orbit. The computations were performed for each 1-degree latitude-longitude cell for 117 wavelengths in the range $0.2-1.0 \mu \mathrm{m}$ and ten spectral intervals in the range $1.0-10 \mu \mathrm{m}$. For each wavelength and spectral interval, a set of monochromatic radiative flux transfer equations is solved for an absorbing/multiple-scattering atmosphere using the Delta-Eddington method of Joseph et al. (1976), based on the Henyey-Greenstein phase function which is an extension of the Eddington method described in Shettle and Weinman (1970). At ultraviolet-visible wavelengths we include ozone absorption and Rayleigh scattering by air. For the near-IR wavelengths we include absorption by water vapour, carbon dioxide and methane. We include scattering and absorption by clouds (low, middle and high) and aerosols, and reflection from the Earth's surface. The treatment of cloud optical properties in the model can be found in Hatzianastassiou and Vardavas $(1999,2001)$ and Hatzianastassiou et al. (2004c, 2005). Note, that aerosols within and above clouds are not considered in this study, due to missing information. This introduces an underestimate of the aerosol effect in the case of absorbing aerosols above clouds (e.g. Keil and Haywood, 2003). In particular, studies (e.g. Haywood and Shine, 1997; Haywood and Ramaswamy, 1998) have shown that black carbon above clouds exerts a DRE that may be greater than that in clear skies by more than a factor of 10, the magnitude of the increase being a function of the cloud optical depth, the surface reflectance and the solar zenith angle. This underestimation becomes particularly important in biomass burning regions where aerosols are lofted to great heights. Reflection of incident solar radiation from the Earth's surface is treated as explained in detail by Hatzianastassiou et al. (2005). In brief, the surface reflectivity, $R_{g}$, for each 1-degree grid cell, is computed considering the fractional coverage of the grid cell's reflecting surface by four general types of surface: land, ocean, snow and ice (frozen ocean). Information for fractional coverage for each surface type is obtained from ISCCP-D2 data (Rossow et al., 1996). The ocean reflectivity, $R_{o}$, is computed using Fresnel reflection as function of incidence angle corrected for a non-smooth surface, with the condition that if Fresnel reflectivity is greater than ice- or snow reflectivity, which occurs for low solar elevations, then the reflectivities of ice or snow are set equal to the Fresnel (see Hatzianastassiou et al., 2005). Snow and sea-ice albedo values are based on recent estimates, whereas data for land albedo were derived from Earth Radiation Budget Experiment (ERBE) data for clear sky, while overcast albedos were obtained by modifying the corresponding clear-sky values for diffuse radiation conditions. The model allows for spectral dependence of surface reflectivity in the UV-visible and near-IR (which is shown to be very important, Wei et al., 2001), but also for different values for direct and diffuse solar radiation. The model was run for all days of each year of the study period (1984-1995) to account accurately for the variations in the solar zenith angle, declination and eccentricity of the orbit of the Earth around the sun.

The SW aerosol DRE (denoted henceforth as $\Delta F$ ), or more precisely the "aerosol flux change", is the effect of aerosols on the SW radiation budget at TOA, at the Earth's surface, or within the atmosphere, and it is given by

$\Delta F=F-F_{\text {no-aerosol }}$

where $F$ and $F_{\text {no-aerosol }}$ are the net incoming (downward upward) $\mathrm{SW}$ radiative fluxes with and without aerosols. The DRE components $\Delta F_{\mathrm{TOA}}, \Delta F_{\text {atmab }}, \Delta F_{\text {surf }}$, and $\Delta F_{\text {surfnet }}$, represent the effect of aerosols on the net incoming (absorbed) radiation at TOA, within the atmosphere, and at the Earth's surface. As far as it concerns $\Delta F_{\mathrm{TOA}}$, it is essentially the change of the outgoing (reflected) SW radiation at TOA, since the incoming extraterrestrial SW radiation is not affected by aerosols, and therefore $\Delta F_{\mathrm{TOA}}$ will refer to this henceforth. Thus, at TOA Eq. (1) reads

$$
\Delta F_{\mathrm{TOA}}=F_{\text {no-aerosol }}^{\mathrm{TOA}}-F^{\mathrm{TOA}}
$$

Therefore, positive values of $\Delta F$ correspond to decreased outgoing SW radiation at TOA, and increased absorbed SW radiation within the atmosphere and at the Earth's surface, and vice versa.

\subsection{GADS aerosol data}

The aerosol optical properties, AOT, $\omega_{\text {aer }}$, and $g_{\text {aer }}$, used in the radiative transfer model were taken from GADS (Koepke et al., 1997), which provides aerosol particle properties averaged over space and time. The use of the Henyey-Greenstein (HG) phase function, which is defined in terms of a single parameter, i.e. the aerosol asymmetry parameter, is common in most radiative transfer models (see e.g. Yu et al., 2006) for describing the angular distribution of scattered radiation by aerosols. Nevertheless, it has been shown (Marshall et 
Table 1. Mean global and hemispherical (NH, SH) long-term (1984-1995) extinction aerosol optical thickness (AOT), aerosol single scattering albedo $\left(\omega_{\mathrm{aer}}\right)$ and aerosol asymmetry parameter $\left(g_{\mathrm{aer}}\right)$ at the visible wavelength of $0.5 \mu \mathrm{m}$, derived from the Global Aerosol Data Set (GADS) for actual atmospheric and surface conditions for January and July.

\begin{tabular}{llccc}
\hline & & AOT $(0.5 \mu \mathrm{m})$ & $\omega_{\text {aer }}(0.5 \mu \mathrm{m})$ & $g_{\text {aer }}(0.5 \mu \mathrm{m})$ \\
\hline \multirow{3}{*}{ January } & Globe & 0.101 & 0.938 & 0.726 \\
& North Hemisphere & 0.121 & 0.891 & 0.698 \\
& South Hemisphere & 0.082 & 0.986 & 0.754 \\
\hline \multirow{4}{*}{ July } & Globe & 0.093 & 0.934 & 0.720 \\
& North Hemisphere & 0.106 & 0.951 & 0.739 \\
& South Hemisphere & 0.081 & 0.917 & 0.702 \\
\hline
\end{tabular}

al., 1995; Boucher, 1998) that although the HG phase function can advantageously replace the Mie phase function in most flux calculations with small errors, it can introduce significant errors (up to 20\%) in the computation of aerosol radiative effects, depending on solar zenith angle, aerosol size and refractive index. The GADS, and its earlier version (D'Almeida et al., 1991) has been frequently used (e.g. King et al., 1999) for retrieving aerosol optical properties (e.g. Chin et al., 2002; Kinne et al., 2003) or in climate studies (e.g. Morcrette, 2002; Treffeisen et al., 2005). In GADS, the tropospheric aerosol particles are described by 10 main aerosol components, which are representative for the atmosphere and characterized through their size distribution and refractive index depending on the wavelength. These aerosol properties are based on components resulting from aerosol emission, formation, and removal processes within the atmosphere, so that they exist as mixture of different substances, both external and internal. Typical components include water-soluble, water-insoluble, soot, sea-salt and mineral. The optical properties of aerosols are subsequently modeled with Mie theory on the basis of aerosol components, from which weighted sums are used to describe optical properties of the total amount of aerosol particles. A detailed description of the treatment of aerosol optical properties by GADS can be found in Koepke et al. (1997) and Hess et al. (1998). The following optical properties are available by GADS: extinction, scattering and absorption coefficients and optical depths, volume phase function, single scattering albedo and asymmetry parameter. Global distributions of GADS aerosol properties are given as climatologically averaged values both for the periods December through February (northern hemisphere winter) and June through August (northern hemisphere summer) on a $5^{\circ} \times 5^{\circ}$ latitude-longitude resolution. However, to match the spatial resolution of the climatological parameters, especially that of relative humidity to which the aerosol properties are sensitive, the original GADS aerosol optical properties were upscaled to $1^{\circ} \times 1^{\circ}$ latitude-longitude resolution, as explained in Hatzianastassiou et al. (2006). The aerosol properties originally taken from GADS, were re-computed for actual rela- tive humidity values for the aerosol layer in order to compute realistically the aerosol DREs for the 12-year period 19841995. The mean long-term global averages of AOT, $\omega_{\text {aer }}$, and $g_{\text {aer }}$, are given in Table 1. The global annual value of AOT at $0.5 \mu \mathrm{m}$ is found to be equal to 0.097 , whereas the $\omega_{\mathrm{aer}}$, and $g_{\text {aer }}$ values are equal to 0.936 and 0.723 . The $\omega_{\text {aer }}$ value is in quite good agreement with the values of 0.935 and 0.929 provided by Yu et al. (2004) and Takemura et al. (2002), respectively, obtained with the Georgia Tech/Goddard Global Ozone Chemistry Aerosol Radiation and Transport (GOCART) and Spectral Radiation-Transport Model for Aerosol Species (SPRINTARS) models. The AOT value is somewhat smaller than current estimates from climate models, ranging from 0.11 to 0.14 (e.g. Kinne et al., 2006), as well as from the average value of 0.14 based on data from AERONET stations. Nevertheless, note that the AERONET data are point specific, and do not provide complete global coverage, whereas there exist significant differences between the AeroCom models (Kinne et al., 2006). Accurate estimates of AOT are being obtained by multi-wavelength measurements, which are taken with sophisticated instruments onboard modern satellites (e.g. MODIS). However, these are available only from 2000. To overlap with our study period (1984-1995) we relied on the derived AOT data at $0.5 \mu \mathrm{m}$ from the Total Ozone Mapping Spectrometer (TOMS, Torres et al., 2002). The computed TOMS global annual mean AOT for the period 1984-1993 was found to be equal to 0.14, which is higher than ours. Our analysis has shown that the general underestimation of AOT by GADS with respect to TOMS arises primarily over oceans, while there are specific land areas over which the AOT is overestimated. For example, this is the case in Sahara, India, and central America in January, and in eastern Sahara, Australian desert, Europe, eastern USA, and south America in July. Moreover, it seems that GADS fails to reproduce some regional features, such as that from biomass burning in the Congo basin (see also Hatzianastassiou et al., 2004a), though it performs rather satisfactorily in reproducing other patterns such as the export of African dust across the Atlantic or the biomass burning in south America. Such deficiencies in GADS, which have 
to be improved in the future, are rather expected given that the GADS dataset has limitations since it was created to represent a comprehensive aerosol climatology by compiling aerosol data on a global basis, that existed from different measurements and models by the 1990s. Since then, a large amount of information on aerosol properties has been accumulated from surface and satellite measurements. Detailed discussions of GADS aerosol properties can be found in Hatzianastassiou et al. (2004a, 2006).

\subsection{Surface and atmospheric data}

The water vapour and temperature data were taken from the GEOS-1 reanalysis product (6-hourly), averaged to a daily temporal resolution. Atmospheric temperature and specific humidity profiles for the years 1984 through to 1995 were used to compute the mean relative humidity of the aerosol layer. The associated uncertainty is about $3^{\circ} \mathrm{K}$ for temperature on average, and $20-25 \%$ for the atmospheric column precipitable water (Zhang et al., 2006). Cloud data on a $1^{\circ} \times 1^{\circ}$ resolution were taken from the NASA-Langley data set based on GEWEX ISCCP DX cloud climatologies. The mean daily $1^{\circ} \times 1^{\circ}$ NASA-Langley cloud data were compiled by processing the 3-hourly ISCCP-DX pixel-level data, which contain radiance and cloud retrieval information from geosynchronous and polar orbiting satellites sampled to a nominal resolution of $30 \mathrm{~km}$. All $30 \mathrm{~km}$ DX pixels within a grid cell are averaged analogously to the methods of ISCCP (e.g. Rossow et al., 1996) to produce gridded radiance and cloud products. The NASA Langley $1^{\circ} \times 1^{\circ}$ cloud data include: cloud amount, cloud-top pressure, cloud-top temperature, liquid water path, and optical depth for total clouds. They also provide cloud amount and cloud-top temperature for low-, mid-, and high-level clouds, as well as cloud amount, cloud-top temperature, cloud optical depth, and cloud albedo separately for ice and liquid water phase clouds. The uncertainties in these products, which are responsible for uncertainty in computed radiative fluxes, and hence DREs, are extensively discussed by Rossow and Schiffer (1999). Although clouds have, for a long time, been highlighted as the major source of uncertainty, they are not considered thus any more (Zhang et al., 2006), since the quality of ISCCP data has been drastically improved (for example, biases in cloud amounts have been generally reduced to $\leq 0.05$, whereas biases in cloud-top temperature have been reduced to $\leq 2-4^{\circ} \mathrm{K}$, (Rossow and Schiffer, 1999)). The surface reflection was computed by using surface-type cover fractions on a mean daily and 1-degree geographical cell resolution for the years 1984-1995. Ice/snow cover data were taken from ISCCP, while surface type classification maps were obtained from other high resolution data sets (Stackhouse et al., 2002). A complete topography scheme is included in the model, which uses the NASA DAO GEOS-1 surface pressure, gridded on $1^{\circ} \times 1^{\circ}$ cells.
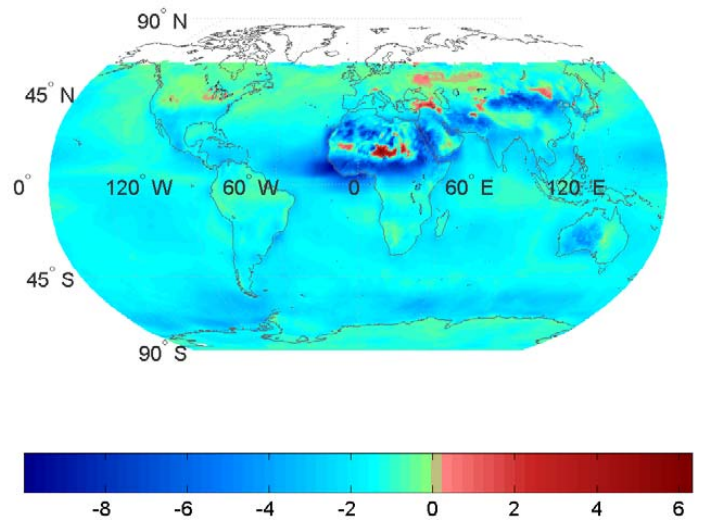

(a)

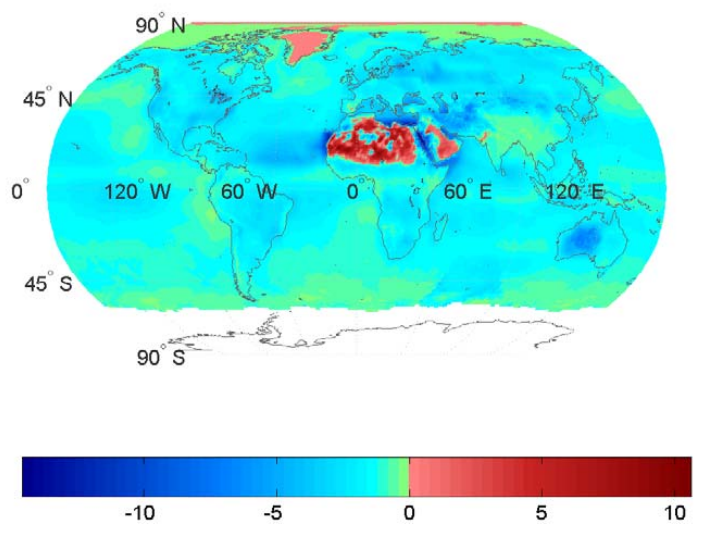

(b)

Fig. 1. Global distribution of the aerosol direct radiative effect (DRE) on the outgoing shortwave radiation at top-of-atmosphere (aerosol DRE $\Delta F_{\mathrm{TOA}}, \mathrm{W} \mathrm{m}^{-2}$ ), for (a) January and (b) July.

\section{Shortwave aerosol direct radiative effect computa- tions}

The model total SW mean monthly (winter and summer) aerosol DREs for each cell ( $1^{\circ}$ longitude-latitude) are given at TOA, in the atmosphere and at the surface. At TOA, the change in planetary albedo $\left(\Delta R_{p}\right)$ due to the presence of aerosols is also given.

\subsection{Aerosol direct radiative effect at the top of atmosphere $\left(\Delta F_{\mathrm{TOA}}\right)$}

The average (1984-1995) change of outgoing SW radiation (OSR) at TOA due to aerosols (aerosol direct radiative effect, $\Delta F_{\mathrm{TOA}}$ ), for all-sky conditions, is given in Fig. 1. According to Eq. (2), negative values indicate increased OSR, i.e. solar radiative cooling effect of the Earth-atmosphere system. In contrast, positive $\Delta F_{\mathrm{TOA}}$ values indicate decreased OSR due to aerosols, or a warming radiative effect. Given that the incoming SW radiation remains unchanged, the change of planetary albedo $\left(\Delta R_{p}\right)$ is directly dependent on $\Delta F_{\mathrm{TOA}}$. Thus, positive and negative values of $\Delta R_{p}$ 

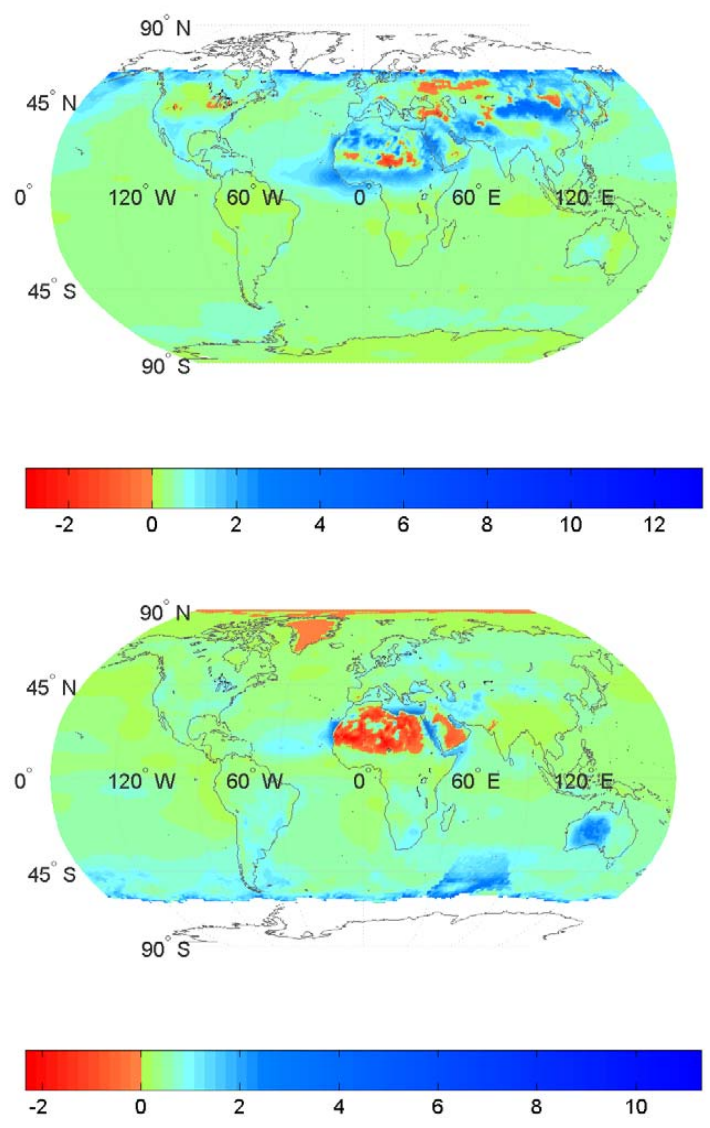

Fig. 2. Global distribution of change in planetary albedo $\left(\Delta R_{p}\right.$, in $\%$ ) due to the aerosol direct radiative effect (DRE), for (a) January and (b) July.

in Fig. 2 correspond to increased and decreased planetary albedo, respectively, due to aerosols (expressed in absolute percentage values).

In general, natural plus anthropogenic aerosols modify the reflected SW radiation by the Earth-atmosphere system by about -15 to $10 \mathrm{~W} \mathrm{~m}^{-2}$ (or -3 to $13 \%$ in terms of $\Delta R_{p}$, Fig. 2). Over most of the globe the change is smaller than $5 \mathrm{~W} \mathrm{~m}^{-2}$ (or $2 \%$ ). Aerosols mostly increase the OSR (negative and positive values of $\Delta F_{\mathrm{TOA}}$ and $\Delta R_{p}$, respectively) producing thus planetary cooling. However, they also produce a warming of the Earth-atmosphere system by decreasing the outgoing SW radiation at TOA by up to $10 \mathrm{~W} \mathrm{~m}^{-2}$ (or $-3 \%$, Fig. 2). This occurs over high-latitude regions with strong surface albedo, such as Greenland in July and Siberia in January, as well as over continental areas (e.g. Sahara, Arabian peninsula) with large surface albedo and significant loads of absorbing aerosols. The sign of DRE at TOA is determined by $\omega_{\text {aer }}$, AOT and surface albedo, $R_{g}$. Therefore, combinations of these parameters can lead to a changing sign of $\Delta F_{\mathrm{TOA}}$ and $\Delta R_{p}$ with time over the same location (e.g. planetary warming over Siberia in winter against planetary cooling in summer), and also to a different sign of $\Delta F_{\mathrm{TOA}}$ and $\Delta R_{p}$ over adjacent areas (e.g. planetary cooling over sub-Sahel and along the Atlantic Ocean tropical zone extending from northern Africa through central America, against planetary warming over highly reflecting Saharan desert areas). The role of $\omega_{\text {aer }}$ for $\Delta F_{\mathrm{TOA}}$ is demonstrated by the fact that our study gives planetary warming over Sahara and Arabia (Figs. 1 and 2), whilst a cooling was found by Reddy et al. (2005) using $\omega_{\text {aer }}>0.95$.

Although planetary warming over these regions is suggested by other results (see e.g. Yu et al., 2004), there is evidence (e.g. Kaufman et al., 2001; Dubovik et al., 2002; Cattrall et al., 2003; Haywood et al., 2003) that dust absorption could be much weaker. According to our GADS-based data, the $\omega_{\text {aer }}$ values over Sahara and Arabia are equal to about 0.85 . To assess a possible overestimation of dust absorption by GADS, we performed a sensitivity analysis that showed that a $6 \%$ larger $\omega_{\text {aer }}$, involving $\omega_{\text {aer }}$ values of $\approx 0.91$ over Sahara and Arabia, has increased $\Delta F_{\mathrm{TOA}}$ over these regions by $2-6 \mathrm{~W} \mathrm{~m}^{-2}$ in January, and by $4-9 \mathrm{~W} \mathrm{~m}^{-2}$ in July, resulting thus in negative $\Delta F_{\mathrm{TOA}}$, i.e. planetary cooling, in agreement with Reddy et al. (2005).

Planetary warming produced by aerosols in high-latitude and polar regions, such as Greenland, are of much interest because of its relation to climate change issues (melting of ice, e.g. Rignot and Kanagaratnam, 2006). Negative DRE values of similar or even stronger magnitude are also expected at least over the Arctic in January, because of the presence of Arctic haze (e.g. Hu et al., 2005; Yamanouchi et al., 2005) involving long-range transport of anthropogenic pollution from industrialized areas in Europe, North America and Asia. Such features do not appear in Figs. 1 and 2, however, because they correspond to areas with missing data.

The largest values of $\Delta F_{\mathrm{TOA}}$ occur in tropical and subtropical latitudes, and especially over continental desert areas (e.g. Sahara, Arabian peninsula, Taklimakan and Gobi in Asia, and central Australia), over oceanic areas over which are transported dust and smoke from biomass burning (e.g. off the coast of west Africa in the tropical Atlantic Ocean, Arabian Sea) and over remote oceanic areas with intense production of sea-spray (storm-track zone of the Southern Hemisphere). The features shown in Fig. 1 are in agreement with those found from satellite-based studies (e.g. Loeb and Manalo-Smith, 2005; Yu et al., 2006), though some other features such as those associated with dust transport from Asia across the Pacific Ocean, are not well captured by GADS properties, perhaps due to the different periods considered (i.e. 1984-1995 here, against after 2000 in satellitebased studies). The magnitude of $\Delta F_{\mathrm{TOA}}$ and $\Delta R_{p}$ for a specific place on the globe is determined by AOT, cloud cover and surface albedo, apart from the incoming solar flux. Thus, large negative values, up to $-9 \mathrm{~W} \mathrm{~m}^{-2}$, appear in regions with small cloudiness and significant aerosol loads, e.g. subSahel, Gobi and Australian deserts, as well as Middle-East and India in January. In July, large negative values (up to 
$-15 \mathrm{~W} \mathrm{~m}^{-2}$ ) exist over limited maritime areas such as the eastern Mediterranean basin and the Red Sea, and secondarily over continental areas such as Australia. Note that highly populated and industrialized urban areas such as Europe and North America are found to have relatively smaller values of $\Delta F_{\mathrm{TOA}}$ (up to $2 \mathrm{~W} \mathrm{~m}^{-2}$ ). We note that small values of aerosol DRE at TOA do not exclude important aerosol effects taking place within the Earth-atmosphere system, since the effect at TOA is the sum of the effects of aerosols in the atmosphere and at the surface. The aerosol effects on the radiation budgets of the atmosphere and surface are examined separately, in the following two subsections.

Overall, the large modifications of OSR produced by aerosols on a climatological basis, equivalent to changes in planetary albedo of $\Delta R_{p}= \pm 1-2 \%$ at the geographical cell level, can have a strong climatic impact. Aerosol modifications to spatial gradients in OSR can affect general circulation patterns in the atmosphere and hence climate, as shown by GCM studies (Kristánsson et al., 2005; Lau et al., 2006).

3.2 Aerosol direct radiative effect in the atmosphere $\left(\Delta F_{\text {atmab }}\right)$

The aerosol DRE on the atmospheric absorption of SW radiation under all-sky conditions, $\Delta F_{\text {atmab }}$, is very important and can be as large as $35 \mathrm{~W} \mathrm{~m}^{-2}$ (Fig. 3). Nevertheless, over the oceans it is generally $\Delta F_{\text {atmab }}<3 \mathrm{~W} \mathrm{~m}^{-2}$, whereas over most continental areas it is $\Delta F_{\text {atmab }}<15 \mathrm{~W} \mathrm{~m}^{-2}$. The largest values of $\Delta F_{\text {atmab }}\left(15-35 \mathrm{Wm}^{-2}\right)$ are found over areas characterized by significant amounts of absorbing aerosols (such as mineral-dust or soot), especially over highly reflecting surfaces (surface albedo $>0.3$ ) in tropical and subtropical latitudes, but large values are also found over the Middle-East, South and South-East Asia, Europe, USA, South America, South Africa, and Australia. Large values of $\Delta F_{\text {atmab }}$ are found over oceans only for transported aerosols of continental origin. This occurs across the tropical Atlantic due to long-range transport of desert dust at higher atmospheric levels (e.g. Formenti et al., 2003; Moulin and Chiapello, 2004) by the "harmattan" trade winds during the dry season (this transport is shifted northwards in July due to the changed atmospheric circulation, Azores anticyclone and thermal low of Pakistan), as well as over the Yellow and Japan Seas due to Asian dust exported from the Gobi desert (e.g. Sun et al., 2001; Liu et al., 2003). The strong increase in atmospheric absorption of solar radiation is either associated with large mass concentrations of absorbing mineral aerosol components or with significant (but smaller) concentrations of strongly absorbing soot or water soluble and insoluble components, especially in the presence of large amounts of solar radiation and over highly reflecting surfaces underneath. The enhancement of absorbed solar radiation is converted into heat. The resulting atmospheric heating rate can be calculated from the First Law of Thermodynamics and hydrostatic
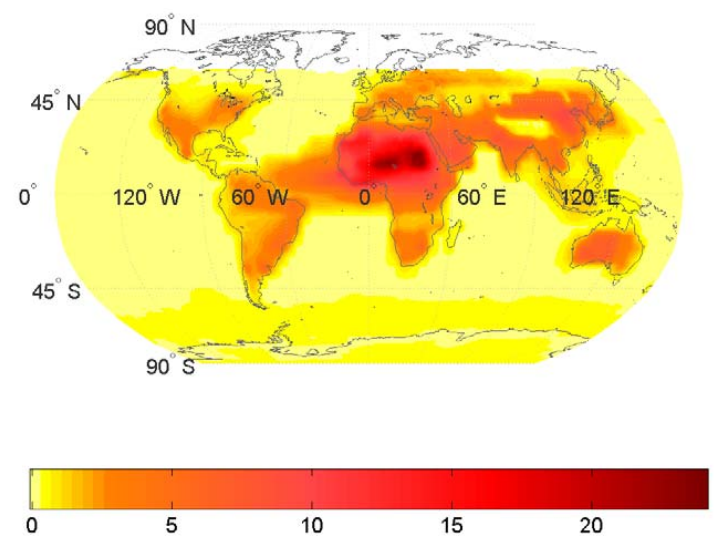

(a)
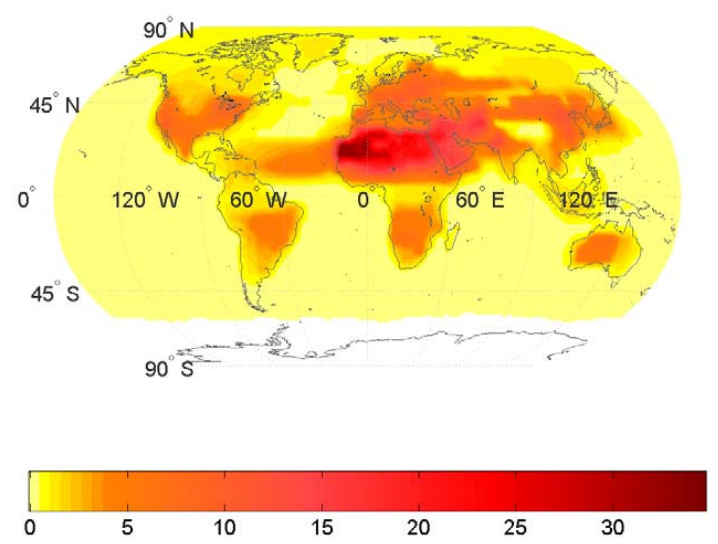

(b)

Fig. 3. Global distribution of the aerosol direct radiative effect (DRE) on the atmospheric absorption of shortwave radiation (aerosol DRE $\Delta F_{\text {atmab }}, \mathrm{W} \mathrm{m}^{-2}$ ), for (a) January and (b) July.

equilibrium

$\frac{\partial T}{\partial t}=\frac{g}{c_{p}} \frac{\Delta F}{\Delta P}$

where $\partial T / \partial t$ is the heating rate $\left(\mathrm{Kday}^{-1}\right), g$ is the acceleration due to gravity, $c_{p}$ the specific heat capacity of air at constant air pressure $\left(\sim 1006 \mathrm{~J} \mathrm{Kg}^{-1} \mathrm{~K}^{-1}\right)$ and $P$ is the atmospheric pressure, respectively. The estimated $\Delta F_{\text {atmab }}$ translates into an atmospheric heating rate of $0.98 \mathrm{~K} \mathrm{day}^{-1}$ for $\Delta F_{\text {atmab }}=35 \mathrm{~W} \mathrm{~m}^{-2}$ for $\Delta P=300 \mathrm{mb}$ (mid-latitude pressure width of troposphere), whereas the atmospheric heating rate over oceans is $<0.14 \mathrm{~K} \mathrm{day}^{-1}$ (for $\Delta F_{\mathrm{atmab}}<5 \mathrm{~W} \mathrm{~m}^{-2}$ ).

\subsection{Aerosol direct radiative effect at surface $\left(\Delta F_{\text {surfnet }}\right)$}

Through scattering and absorption, together natural and anthropogenic aerosols decrease drastically the downwelling and absorbed solar radiation at the Earth's surface by up to 45 and $35 \mathrm{~W} \mathrm{~m}^{-2}$, respectively. As shown in Fig. 4, large values of $\Delta F_{\text {surfnet }}$ are found over continental areas, especially over deserts and polluted regions of the world. Thus, the absorbed SW radiation by the surface is decreased by 

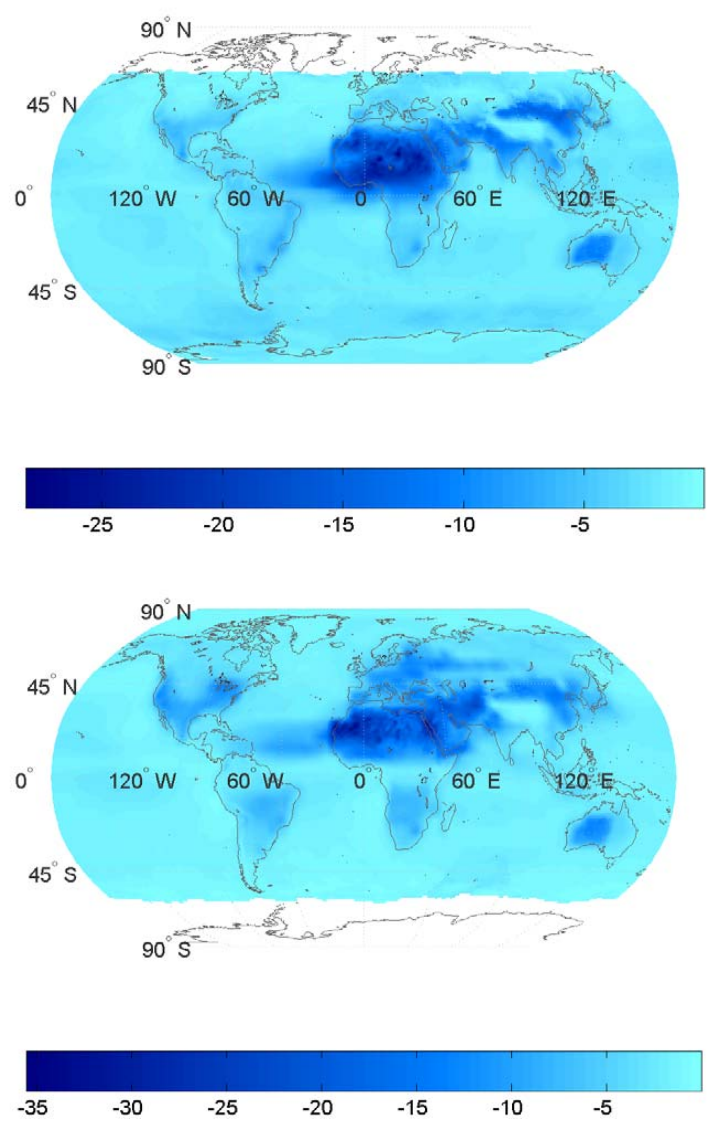

Fig. 4. Global distribution of the aerosol direct radiative effect (DRE) on the absorbed shortwave radiation by the Earth's surface (aerosol DRE $\Delta F_{\text {surfnet }}, \mathrm{W} \mathrm{m}^{-2}$ ), for (a) January and (b) July.

$20-35 \mathrm{~W} \mathrm{~m}^{-2}$ in the Sahara and Sahel, by $10-20 \mathrm{~W} \mathrm{~m}^{-2}$ in the sub-Sahel, Arabian peninsula and Middle-East, and by $5-15 \mathrm{~W} \mathrm{~m}^{-2}$ in Europe, India, eastern China and USA. The aerosol optical thickness, AOT, is the determinant parameter for $\Delta F_{\text {surfnet }}$. Smaller $\Delta F_{\text {surfnet }}$ values $\left(<5-7 \mathrm{~W} \mathrm{~m}^{-2}\right)$ are found over oceans, due to the optically thin aerosol layers there. The strong discontinuity of $\Delta F_{\text {surfnet }}$ between land and ocean can be attributed to the rapidly changing optical properties of the aged (transported) aerosols in GADS. Only in oceanic areas close to land and areas where long-range transport of aerosols takes place, the values of $\Delta F_{\text {surfnet }}$ become as large as $10-15 \mathrm{~W} \mathrm{~m}^{-2}$. The strong decrease in surface solar radiation due to aerosols produces strong surface radiative cooling. For oceanic layers of $10 \mathrm{~m}$ depth, and using Eq. (3) and a $c_{p}$ of water equal to $\sim 4184 \mathrm{~J} \mathrm{Kg}^{-1} \mathrm{~K}^{-1}$, a value of $-7 \mathrm{~W} \mathrm{~m}^{-2}$ for $\Delta F_{\text {surfnet }}$ translates to an oceanic water cooling rate of $-0.015 \mathrm{~K} \mathrm{day}^{-1}$. For land, using a $1 \mathrm{~m}$ deep soil layer with a $c_{p}$ value of $800 \mathrm{~J} \mathrm{Kg}^{-1} \mathrm{~K}^{-1}$, the estimated cooling rate is equal to $-1.24 \mathrm{~K} \mathrm{day}^{-1}$ for $\Delta F_{\text {surfnet }}$ equal to $-15 \mathrm{~W} \mathrm{~m}^{-2}$.

The drastic decrease of surface solar radiation due to aerosols, an effect which is called global dimming, is very important since it can modulate the hydrological cycle (e.g. Jacobson, 2001; Kaufman et al., 2002; Ramanathan et al., 2001). Recent studies (e.g. Lau et al., 2006) have shown that on time-scales of climate change, the cooling of the Earth's surface might lead to a gradual spin-down of the tropical water cycle and the eventual weakening of the Asian monsoons. The values of $\Delta F_{\text {surfnet }}$ are larger compared to those of $\Delta F_{\mathrm{TOA}}$ and $\Delta F_{\text {atmab }}$ (Figs. 1 and 3 , respectively), so that the aerosol DRE is much larger at the Earth's surface than at TOA or in the atmosphere. This is further discussed in the next section.

3.4 Ratio of top-of-atmosphere to surface shortwave aerosol direct radiative effect

The three types of aerosol DRE satisfy the conservation condition

$\Delta F_{\mathrm{TOA}}+\Delta F_{\text {surfnet }}+\Delta F_{\mathrm{atmab}}=0$

The atmospheric absorption of aerosols $\Delta F_{\text {atmab }}$ and $\Delta F_{\text {surfnet }}$ can be estimated from satellite observations only indirectly (e.g. Bellouin et al., 2003). When $\Delta F_{\text {atmab values }}$ are extremely small, then $\Delta F_{\mathrm{TOA}}$ and $\Delta F_{\text {surfnet }}$ are essentially equal and opposite and this permits the surface DRE to be estimated from the DRE at TOA (Ramanathan et al., 2001), as in the case of purely scattering aerosols.

Computed values of the ratio $\Delta F_{\text {surfnet }} / \Delta F_{\mathrm{TOA}}$ are given in Fig. 5. The ratio ranges from -10 to 10 over most of the oceanic and land areas, demonstrating the dominance of the surface to TOA aerosol DRE. Note that in cases of very small $\Delta F_{\mathrm{TOA}}$ values, the ratio's magnitude can be much larger than 15 , but without any physical meaning, and hence such areas have been masked in Fig. 5 (white shaded areas e.g. in Sahara and Arabian peninsula). When the ratio takes values close to 1 , the magnitude of surface forcing equals that at TOA, which means that $\Delta F_{\text {atmab }}$ is negligible. In case of large positive $\Delta F_{\text {surfnet }} / \Delta F_{\mathrm{TOA}}$ values, the ratio $\Delta F_{\mathrm{atmab}} / \Delta F_{\mathrm{TOA}}$ is also large when there are strongly absorbing aerosols in the atmosphere $\left(\omega_{\mathrm{aer}}<0.95\right)$, e.g. over southern and eastern Asia, sub-Sahel, south Africa, and Europe in July, especially when surface albedo is large; this is the case of northern polar latitudes in July. Regions with blue-green color correspond to opposite sign values of DRE at TOA and surface; given that $\Delta F_{\text {surfnet }}$ is always negative (see Fig. 4), these regions must have positive $\Delta F_{\mathrm{TOA}}$ values, i.e. they are characterized by planetary warming due to aerosols. This occurs over regions with large surface albedo and strongly absorbing aerosols above, e.g. Sahara, Arabian peninsula, Greenland.

Further, our results indicate that over many areas of the globe the surface DRE of aerosols can be up to 3-4 times larger than at TOA, in general agreement with the findings of Ramanathan et al. (2001) and Kaufman et al. (2002), but there are also many areas where the ratio exceeds 5 , as also reported recently by Chung et al. (2005). 

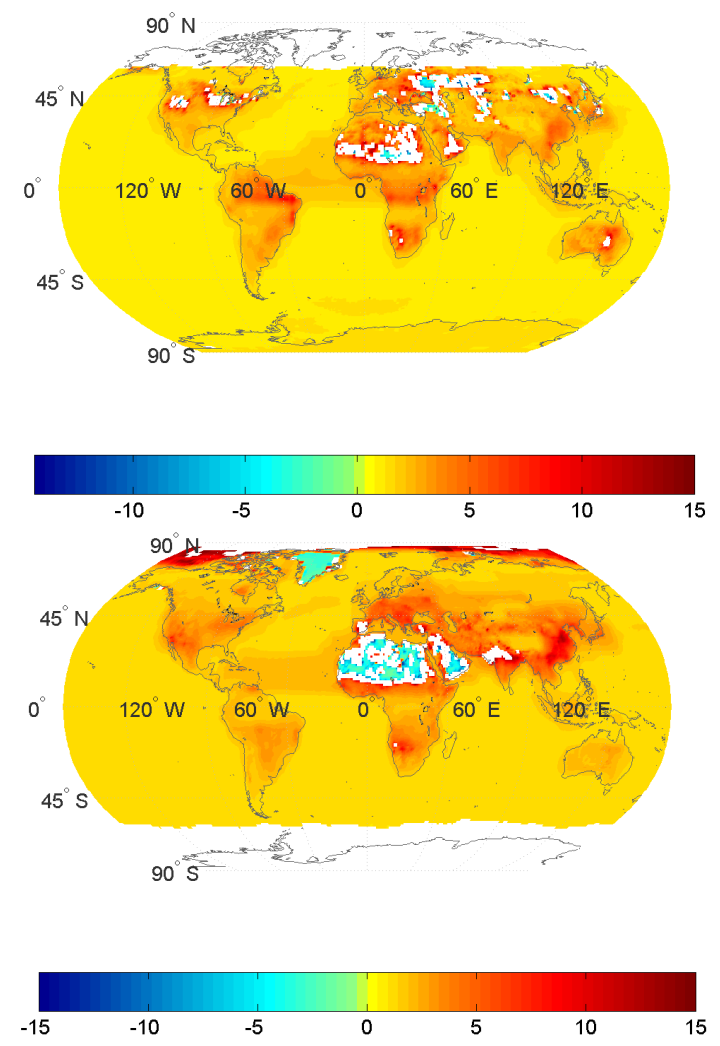

(b)

Fig. 5. Global distribution of the ratio of aerosol direct radiative effects $\Delta F_{\text {surfnet }} / \Delta F_{\mathrm{TOA}}$, for (a) January and (b) July. Extremely small $\Delta F_{\text {TOA }}$ values, close to zero, which are associated with large ratios with no physical significance have been omitted.

\subsection{Global and hemispherical averages of aerosol direct ra-} diative effects

Global and hemispherical averages of SW DREs at TOA, in the atmosphere and at surface were also estimated, by including surface area weighting in the computations, and the results are given in Table 2 and Fig. 6. The largest DRE arising from natural plus anthropogenic aerosols is found at the surface, where it is about twice the DREs in the atmosphere and at TOA, irrespective of the hemisphere; the downward and absorbed fluxes are decreased by about 3.9 and $3.2 \mathrm{~W} \mathrm{~m}^{-2}$, respectively, on a global scale. In the atmosphere, solar radiation absorption increases by about $1.6 \mathrm{~W} \mathrm{~m}^{-2}$, and the globally averaged reflected solar flux to space increases by about $1.6 \mathrm{~W} \mathrm{~m}^{-2}$. Our model value at TOA is in good agreement with other recent estimates from measurement-based approaches (e.g. Loeb and Manalo-Smith, 2005; Yu et al., 2006, review paper), ranging between -1.5 and $-2.0 \mathrm{~W} \mathrm{~m}^{-2}$. For both $\Delta F_{\text {atmab and }}$ $\Delta F_{\text {surfnet }}$ there are large inter-hemispherical differences, with the largest effect of aerosols taking place in the more polluted and less cloudy northern hemisphere. More specifically, the

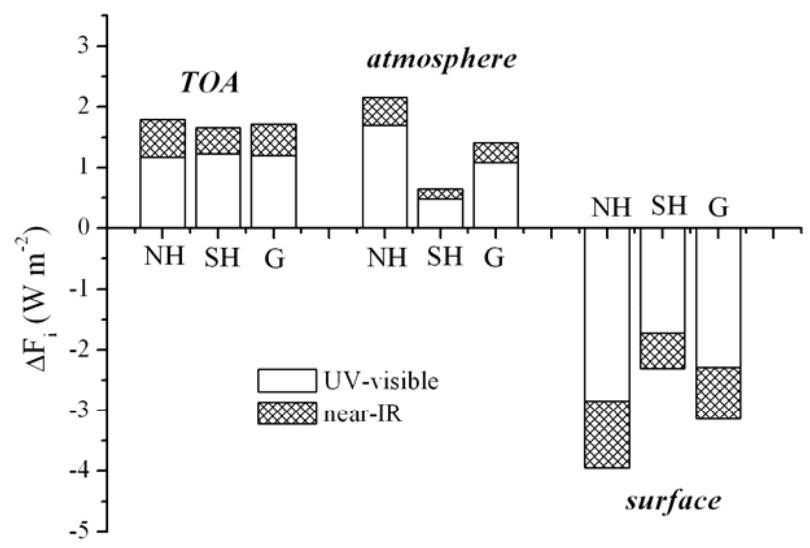

(a)

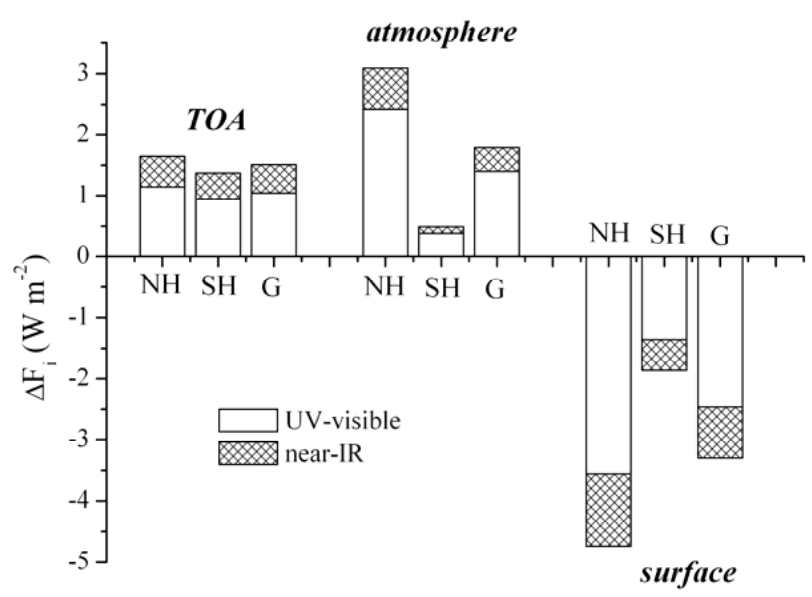

(b)

Fig. 6. Hemispherical and global averages of aerosol direct radiative effects (DRE) on the shortwave radiation at: TOA $\left(\Delta F_{\mathrm{TOA}}\right)$, in the atmosphere $\left(\Delta F_{\text {atmab }}\right)$, and at surface $\left(\Delta F_{\text {surfnet }}\right)$, for (a) January and (b) July. Each forcing is divided in ultraviolet(UV)-visible and near-infrared (IR) components. $\mathrm{NH}, \mathrm{SH}$ and G correspond to North Hemisphere, South Hemisphere and Globe.

northern hemispherical values for $\Delta F_{\text {atmab }}$ are larger than the southern ones by factors of 3.3 and 6.3 in January and July, respectively, while the corresponding factors for $\Delta F_{\text {surfnet }}$ are 1.7 and 2.5 , i.e. they are quite smaller. On the contrary, very small inter-hemispherical differences are found for $\Delta F_{\mathrm{TOA}}$, as a result of the combination of $\Delta F_{\mathrm{atmab}}$ and $\Delta F_{\text {surfnet. }}$ In general, the magnitude of global hemispherical aerosol DREs at surface and in the atmosphere is slightly (by factors 1.3 and 1.1, respectively) larger in July than in January. Also, significant differences in the relative importance of the DREs at TOA, in the atmosphere and at the surface, are found between the two hemispheres. For example, the ratio $\Delta F_{\text {surfnet }} / \Delta F_{\text {atmab }}$ is about -1.7 in the northern hemisphere and -3.7 in the southern hemisphere. This inter-hemispherical contrast indicates the different nature of aerosols, being much more scattering in the cleaner southern 
Table 2. Mean global and hemispherical $(\mathrm{NH}, \mathrm{SH})$ all-sky shortwave aerosol direct radiative effect (DRE, denoted as $\Delta F$ in $\mathrm{W} \mathrm{m}^{-2}$ ) for January and July. The DRE components are given in terms of: outgoing radiation at TOA $\left(\Delta F_{\mathrm{TOA}}\right)$, radiation absorbed in the atmosphere $\left(\Delta F_{\text {atmab }}\right)$, downward radiation at surface $\left(\Delta F_{\text {surf }}\right)$, and net downward (absorbed) radiation at surface $\left(\Delta F_{\text {surfnet }}\right)$.

\begin{tabular}{llcccc}
\hline & $\Delta F_{\mathrm{TOA}}$ & $\Delta F_{\text {atmab }}$ & $\Delta F_{\text {surf }}$ & $\Delta F_{\text {surfnet }}$ \\
\hline \multirow{4}{*}{ January } & Globe & -1.72 & 1.41 & -3.87 & -3.13 \\
& North Hemisphere & -1.79 & 2.16 & -4.96 & -3.95 \\
& South Hemisphere & -1.66 & 0.65 & -2.79 & -2.31 \\
\hline \multirow{4}{*}{ July } & Globe & -1.51 & 1.79 & -4.0 & -3.3 \\
& North Hemisphere & -1.65 & 3.09 & -5.83 & -4.74 \\
& South Hemisphere & -1.37 & 0.49 & -2.17 & -1.86 \\
\hline
\end{tabular}

hemisphere compared to the more absorbing nature of those in the northern hemisphere that includes many anthropogenic sources and most of the world's deserts. As for the spectral contribution to the total SW DREs (see Fig. 6), it appears that for all DRE components, both for summer and winter and both hemispheres, the largest contribution (about 70-80\%) is in the UV-visible wavelengths.

A comparison of our computations of aerosol DREs at TOA and at the Earth's surface under all-sky conditions with some other estimates based on satellite observations and multi-component aerosol models is presented in Table 3. Of course, the estimates given in this table are not homogeneous. However, they are given just for inter-comparison with our computations. Given the different approaches, model- or satellite-based estimates, the different aerosol properties, the different properties of the rest atmospheric and surface parameters, the different time periods, the different spatial and temporal resolutions etc, a perfect agreement cannot be expected. In order to assess the differences in each case, a large numbers of parameters should be considered and examined carefully, which is beyond the scope of this study. There are fewer results for $\Delta F_{\text {surfnet }}$ published in the literature than for $\Delta F_{\mathrm{TOA}}$. The present estimate of all-sky global mean $\Delta F_{\mathrm{TOA}}$ $\left(-1.62 \mathrm{~W} \mathrm{~m}^{-2}\right)$ is larger than previous estimates obtained with aerosol models (ranging from -0.24 to $-1.04 \mathrm{~W} \mathrm{~m}^{-2}$ ), while it is very close to the model-based estimate by Jacobson (2001) and to the estimates by Yu et al. (2004 ${ }^{\mathrm{a}}, 2006$, see Table 3) based on measurement-based approaches. Note that the present model estimates include uncertainties related to possible underestimation of AOT by GADS, as explained in Sect. 2.2. Based on our model sensitivity (see e.g. Hatzianastassiou et al., 2004b) an underestimation of AOT by $25 \%$, may lead to smaller magnitudes of the aerosol DREs in Table 2 by $0.39 \mathrm{~W} \mathrm{~m}^{-2}$ for $\Delta F_{\mathrm{TOA}}$, and $0.68 \mathrm{~W} \mathrm{~m}^{-2}$ for $\Delta F_{\text {surfnet }}$. The global mean $\Delta F_{\text {surfnet }}$ from this study $\left(-3.22 \mathrm{~W} \mathrm{~m}^{-2}\right)$ is slightly smaller in magnitude than the estimates by Yu et al. (2004 ${ }^{\mathrm{a}}$, see Table 3 ) and, especially, by Jacobson (2001), though relatively close to the estimates by Yu et al. (2004 ${ }^{\mathrm{b}}$, see Table 3) and Yu et al. (2006). The dif- ferences with the former two studies should be attributed to differences in atmospheric absorption by aerosols ( $\left.\Delta F_{\text {atmab }}\right)$. For example, Jacobson (2001) reported that $\Delta F_{\text {atmab }}$ is primarily due to absorption by soil dust, certain organic matter and black carbon. It is possible that GADS underestimates the aerosol absorption with respect to the studies by $\mathrm{Yu}$ et al. (2004 ${ }^{\mathrm{a}}$, see Table 3) and Jacobson (2001), thus leading to slightly underestimated $\Delta F_{\text {surfnet }}$ values. The underestimation in this study can be partly explained by the fact that aerosol DRE is not accounted for when aerosols are within and above clouds (see Sect. 2.1). Definitely, the treatment of various aerosol components, the way they are mixed, as well as other factors like the assumed aerosol size distributions, refractive indices, or aerosol formation, emission and removal processes, are crucial for explaining the differences. This is also shown by the different DRE estimates obtained by Yu et al. (2004) using either the GOCART model alone $\left(2004^{\mathrm{b}}\right.$, see Table 3$)$ or combined with the Moderate Resolution Imaging Spectroradiometer (MODIS, 2004 ${ }^{\mathrm{a}}$, see Table 3 ). We note that estimates computed with coupled aerosol and general circulation models are not only based on a restricted number of spectral intervals but are also based on generated global distributions of cloud cover fractions that are not as accurate as those from satellite observations, as used in our study.

Although all-sky aerosol DREs are given in Table 3, the clear- and cloudy-sky DREs are also estimated separately with our modelling approach, in contrast to measurementbased approaches, which have to assume a cloud-sky effect equal to zero to get the all-sky estimate. This is one of the advantages of modelling techniques. According to our results for the period 1984-1995, the cloudy-sky DREs are found to be smaller than the clear-sky ones, as expected. The longterm mean annual ratios $\Delta F_{\text {cloudy }} / \Delta F_{\text {clear }}$ at TOA are equal to $0.25,0.15$ and 0.2 for the northern hemisphere, southern hemisphere and the globe, respectively. At the surface, the corresponding values are equal to $0.48,0.25$ and 0.39 , while in the atmosphere they are equal to $0.71,0.72$ and 0.71 (northern hemisphere, southern hemisphere, globe). 
Table 3. Comparison of published shortwave aerosol DRE (in $\left.\mathrm{W} \mathrm{m}^{-2}\right)$ at TOA $\left(\Delta F_{\mathrm{TOA}}\right)$ and at the Earth's surface $\left(\Delta F_{\text {surfnet }}\right)$ under all-sky conditions*.

\begin{tabular}{lcccccc}
\hline & \multicolumn{3}{c}{$\Delta F_{\mathrm{TOA}}$} & \multicolumn{3}{c}{$\Delta F_{\text {surfnet }}$} \\
\hline & $\mathrm{NH}$ & $\mathrm{SH}$ & Globe & $\mathrm{NH}$ & $\mathrm{SH}$ & Globe \\
\hline Present study & -1.72 & -1.51 & -1.62 & -4.35 & -2.09 & -3.22 \\
Yu et al. (2006) & & & -1.9 & & & -3.4 \\
Reddy et al. (2005) & -1.51 & -0.58 & -1.04 & & & \\
Liao et al. (2004) & & & -0.93 & & & \\
Yu et al. (2004) $^{\mathrm{a}}$ & -1.82 & -1.33 & -1.57 & -4.65 & -2.24 & -3.44 \\
Yu et al. (2004) $^{\mathrm{b}}$ & -1.33 & -0.91 & -1.12 & -3.64 & -1.61 & -2.62 \\
Takemura et al. (2002) & -0.17 & -0.3 & -0.24 & & & -4.6 \\
Jacobson (2001) & & & -1.8 & & & \\
\hline
\end{tabular}

a Obtained with MODIS+GOCART (Georgia Tech/Goddard Global Ozone Chemistry Aerosol Radiation and Transport) integration.

b Obtained with GOCART alone.

* The values of Yu et al. (2004, 2006) have been adjusted for all-sky (from clear-sky) conditions, using a mean (spatial and temporal terms) cloudiness equal to 0.65 (based on satellite ISCCP data) and considering the DRE negligible under cloudy skies.

\section{Summary and conclusions}

In this study, we quantified the global-scale direct radiative effect (DRE) of natural plus anthropogenic aerosols on solar radiation. This was accomplished by using a detailed spectral radiative transfer model covering the UV, visible, and near-IR wavelengths together with spectral aerosol optical properties (optical thickness, single scattering albedo and asymmetry parameter) taken from the Global Aerosol Data Set (GADS). This is in contrast to other similar studies often treating the whole solar spectrum as one spectral interval. The state of the atmosphere (clouds included) and that of the Earth's surface were specified using reanalysis data sets and satellite measurements. Therefore, the DRE on the outgoing SW radiation at the top of atmosphere $\left(\Delta F_{\mathrm{TOA}}\right)$, on atmospheric absorption $\left(\Delta F_{\mathrm{atmab}}\right)$, and on the downward and absorbed SW radiation at the Earth's surface $\left(\Delta F_{\text {surf }}\right.$ and $\Delta F_{\text {surfnet }}$ ) were computed for realistic conditions of the Earth-atmosphere system for the 12-year period 1984-1995. The results are given for January and July at $1^{\circ}$ latitudelongitude resolution for all-sky conditions, but also averaged for the two hemispheres and for the globe, and they represent a climatological assessment of aerosol DREs.

On a mean global basis, natural and anthropogenic aerosols together are found to increase the outgoing SW radiation at TOA (planetary cooling) by about $1.6 \mathrm{~W} \mathrm{~m}^{-2}$, and to radiatively heat the atmosphere (atmospheric heating) by increasing the absorption of solar radiation by about $1.6 \mathrm{~W} \mathrm{~m}^{-2}$. As a result, the downwelling and the absorbed SW radiation by the Earth's surface is found to be decreased (surface cooling) by 3.9 and $3.2 \mathrm{~W} \mathrm{~m}^{-2}$, respectively, due to aerosols. Recently, Yu et al. (2006) presented in a review paper aerosol DRE values over land+ocean from measurementbased approaches under clear-sky conditions. These values when combined and adjusted to all-sky conditions are equal to $-1.9 \mathrm{~W} \mathrm{~m}^{-2}$ at TOA, and $-3.4 \mathrm{~W} \mathrm{~m}^{-2}$ at surface, i.e. they are close to our computations $\left(-1.6\right.$ and $-3.2 \mathrm{~W} \mathrm{~m}^{-2}$, respectively). It should be noted that our computations refer to the DRE of natural plus anthropogenic aerosols. The effect of anthropogenic aerosols only, called direct climate forcing (DCF), can be derived nowadays from new-generation satellite instruments (e.g. MODIS), which are able to distinguish between fine (submicron) and coarse (supermicron) aerosols. Thus, recent estimates under all-sky conditions (e.g. Bellouin et al., 2005) give a DCF at TOA equal to $-0.8 \pm 0.1 \mathrm{~W} \mathrm{~m}^{-2}$ and at surface equal to $-1.9 \pm 0.2 \mathrm{~W} \mathrm{~m}^{-2}$, values that correspond to about $50 \%$ of our computed total aerosol DRE. There are also other model-based estimates of DCF with smaller magnitude, such as those of $-0.65 \mathrm{~W} \mathrm{~m}^{-2}$ by Penner et al. (1998), -0.19 and $-0.1 \mathrm{~W} \mathrm{~m}^{-2}$ by Takemura et al. (2002) and (2005), respectively, and $-0.35 \mathrm{~W} \mathrm{~m}^{-2}$ by Chung et al. (2005).

The magnitude of the combined radiative effect of natural and anthropogenic aerosols at TOA $\left(\Delta F_{\mathrm{TOA}}\right)$, which is equivalent to an increase in planetary albedo of the order of $1 \%$, is very important for the climate of the Earth-atmosphere system, since it is comparable to that of climate forcing induced by elevated concentrations of greenhouse gases (about $2.4 \mathrm{~W} \mathrm{~m}^{-2}$, IPCC, 2001). Nevertheless, the largest DRE occurs at surface $\left(\Delta F_{\text {surfnet }}\right.$, about double $\left.\Delta F_{\mathrm{TOA}}\right)$ having the potential for major effects on surface radiation budget (SRB), evaporation, and the hydrological cycle. The mean global enhanced absorption of solar radiation by $1.5 \mathrm{~W} \mathrm{~m}^{-2}$ translates to an estimated atmospheric heating rate of $0.01 \mathrm{~K} \mathrm{day}^{-1}$. The major part of the computed DREs is for the northern hemisphere, which has most anthropogenic aerosol sources and desert areas, while larger DREs occur in July than in January. 
According to our computations, a large percentage of the incident solar radiation at TOA is radiatively forced by aerosols. More specifically, these percentages can be as large as $13 \%$ at the Earth's surface and TOA, and $7 \%$ in the atmosphere. Furthermore, the aerosol effect on planetary albedo $\left(\Delta R_{p}\right)$ can even change sign. Thus, although it is found that in general, natural and anthropogenic aerosols together cool the Earth-atmosphere system, through scattering of SW radiation back to space, by up to about $15 \mathrm{~W} \mathrm{~m}^{-2}$, aerosols are also found to produce planetary warming (by up to $10 \mathrm{~W} \mathrm{~m}^{-2}$ ) over areas such as Sahara, Arabian peninsula, Siberia and Greenland. Regionally, the aerosol particles warm the atmosphere by absorbing solar radiation by up to $35 \mathrm{~W} \mathrm{~m}^{-2}$. The largest aerosol-induced atmospheric warming occurs above areas characterized by strongly absorbing mineral dust particles, especially over highly reflecting deserts. The estimated $\Delta F_{\text {atmab }}$ values translate into a tropospheric maximum heating rate of $0.98 \mathrm{~K} \mathrm{day}^{-1}$ over land, and $<0.14 \mathrm{~K} \mathrm{day}^{-1}$ over oceans. At the Earth's surface, the downward and absorbed SW radiation is decreased by up to 45 and $30 \mathrm{~W} \mathrm{~m}^{-2}$, respectively, due to aerosol scattering and absorption. Regionally, the ratio of surface to TOA aerosol SW DRE changes from strong negative values of -15 to strong positive values up to 15 , which indicates the important role of both natural and anthropogenic aerosols for surface processes and the surface radiation budget. This strong surface SW cooling combined with an associated atmospheric warming, can have important consequences on atmospheric circulation, since it can create more stable atmospheric conditions (by decreasing the vertical atmospheric temperature gradient) and lower surface evaporation, resulting in less clouds and precipitation, thus enhancing desertification processes, especially in semi-arid regions such as the Mediterranean basin or northern Africa.

The computations presented in this study have uncertainties related to the limitations of the GADS aerosol optical properties used as input data. These uncertainties refer to the quality and incompleteness of measurements, quality of data (refractive index and size distribution) for describing the aerosol components, aerosol height distribution, description of aerosol particles with limited number of components or validity of amount and mixture of components for describing aerosol as an average for a specific location. Another source of uncertainty in the present DREs is the use of aerosol asymmetry parameter for describing the angular distribution of scattering instead of the Mie phase function. Nevertheless, the model results can be considered as reasonable for estimating the direct radiative effect of aerosols, though not for examining time-series. They are also useful for performing detailed spectral analyses of DREs, as shown in this study and those by Hatzianastassiou et al. (2004a, b, 2006). The uncertainties will be reduced in planned future studies by using satellite measurements (TOMS, MODIS), that will provide more accurate estimations of aerosol DREs. Note, however, that the spectral resolution of those satellite-based aerosol properties is still inferior to that provided by GADS.

Acknowledgements. This research was co-funded by the European Social Fund \& National Resources-EPEAEK II - PYTHAGORAS (contract: 1964). The NASA-Langley data were obtained from the NASA Langley Research Center (LaRC) Atmospheric Sciences Data Center (ASDC). The GADS aerosol data were obtained from the Meteorological Institute of the University of Munich, Germany (http://www.meteo.physik.uni-muenchen.de/strahlung/aerosol/ aerosol.htm).

Edited by: A. Laaksonen

\section{References}

Bellouin, N., Boucher, O., Tanré, D., and Dubovik, O.: Aerosol absorption over the clear-sky oceans deduced from POLDER1 and AERONET observations, Geophys. Res. Lett., 30, 1748, doi:10.1029/2003GL017121, 2003.

Bellouin, N., Boucher, O., Haywood, J., and Reddy, M. S.: Global estimate of aerosol direct radiative forcing from satellite measurements, Nature, 438, 1138-1141, 2005.

Boucher, O.: On aerosol direct shortwave forcing and the HenyeyGreenstein phase function, J. Atmos. Sci., 55, 128-134, 1998.

Bush, B. C. and Valero, F. P. J.: Surface aerosol radative forcing at GOSAN during the ACE-Asia campaign, J. Geophys. Res., 108(D23), 8660, doi:10.1029/2002JD003233, 2003.

Cattrall, C., Karder K. L., and Gordon, H. R.: Columnar singlescattering albedo and phase function retrieved from sky radiance over the ocean: Measurements of Saharan dust, J. Geophys. Res., 108, 4287, doi:10.1029/2002JD002497, 2003.

Chin, M., Ginoux, P., Holben, B. N., Chou, M.-D., Kinne, S., and Weaver, C.: The GOCART model study of aerosol composition and aerosol forcing, 12th Symposium of Global Change and Climate Variations, Am. Meteorol. Soc., Albuquerque, New Mexico, 2001.

Chin, M., Ginoux, P., Kinne, S., Torres, O., Holben, B. N., Duncan, B. N., Martin, R. V., Logan, J. A., Higurashi, A., and Nakajima, T.: Tropospheric aerosol optical thickness from the GOCART model and comparisons with satellite and Sun photometer measurements, J. Atmos. Sci., 59, 461-483, 2002.

Christopher, S. A. and Zhang, J.: Shortwave aerosol radiative forcing from MODIS and CERES observations over the oceans, Geophys. Res. Lett., 29, 1859, doi:10.1029/2002GL014803, 2002.

Christopher, S. A., Zhang, J. A., Kaufman Y. J., and Remer L. A.: Satellite-based assessment of top of atmosphere anthropogenic aerosol radiative forcing over cloud-free oceans, Geophys. Res. Lett., 33, L15816, doi:10.1029/2005GL025535, 2006.

Chu, D. A., Kaufman, Y. J., Ichoku, C., Remer, L. A., Tanré D., and Holben, B. N.: Validation of MODIS aerosol optical depth retrieval over land, Geophys. Res. Lett., 29(12), 1617, doi:10.1029/2001GL013205, 2002.

Chung, C. E., Ramanathan, V., Kim, D., and Podgorny, I. A.: Global anthropogenic aerosol direct forcing derived from satellite and ground-based observations, J. Geophys. Res., 110, D24207, doi:10.1029/2005JD006356, 2005.

D’Almeida, G. A., Koepke, P., and Shettle, E. P.: Atmospheric aerosols: Global climatology and radiative characteristics, A. Deepak Publishing, Hampton, Virginia, USA, 560 pp., 1991. 
Dubovik, O., Holben, B. N., Eck, T. F., Smirnov, A., Kaufman, Y. J., King, M. D., Tanré, D., Logan, and Slutsker, Y.: Variability of absorption and optical properties of key aerosol types observed in worldwide regions, J. Atmos. Sci., 59, 590-608, 2002.

Formenti, P., Elbert, W., Maenhaut, W., Haywood, J., and Andreae, M. O.: Chemical composition of mineral dust aerosol during the Saharan Dust Experiment (SHADE) airborne campaign in the Cape Verde region, September 2000, J. Geophys. Res., 108(D18), 8576, doi:10.1029/2002JD002648, 2003.

Granger Morgan, M., Adams, P. J., and Keith, D. W.: Elicitation of expert judgments of aerosol forcing, Clim. Change, 75, 195-214, 2006.

Hatzianastassiou, N. and Vardavas, I.: Shortwave radiation budget of the Northern Hemisphere using International Satellite Cloud Climatology Project and NCEP/NCAR climatological data, J. Geophys. Res., 104, 24 401-24 421, 1999.

Hatzianastassiou, N. and Vardavas, I.: Shortwave radiation budget of the Southern Hemisphere using ISCCP C2 and NCEP/NCAR climatological data, J. Climate, 14, 4319-4329, 2001.

Hatzianastassiou, N., Katsoulis, B., and Vardavas, I.: Global distribution of aerosol direct radiative forcing in the ultraviolet and visible arising under clear skies, Tellus, 56B, 51-71, 2004a.

Hatzianastassiou, N., Katsoulis, B., and Vardavas, I.: Sensitivity analysis of aerosol direct radiative forcings in the ultraviolet visible wavelengths and consequences for the heat budget, Tellus, 56B, 368-381, 2004b.

Hatzianastassiou, N., Fotiadi, A., Matsoukas, C., Pavlakis, K. G., Drakakis, E., Hatzidimitriou, D., and Vardavas, I.: Long-term global distribution of Earth's shortwave radiation budget at the top of atmosphere, Atmos. Chem. Phys., 4, 1217-1235, 2004c.

Hatzianastassiou, N., Fotiadi, A., Matsoukas, C., Drakakis, E., Pavlakis, K. G., Hatzidimitriou, and Vardavas, I.: A 17-year global distribution of Earth's surface shortwave radiation budget, Atmos. Chem. Phys., 5, 2847-2867, 2005,

http://www.atmos-chem-phys.net/5/2847/2005/.

Hatzianastassiou, N., Matsoukas, C., Fotiadi, A., Stackhouse Jr., P. W., Koepke, P., Drakakis, E., Pavlakis, K. G., Hatzidimitriou, D., and Vardavas, I.: Modelling the direct effect of aerosols in the solar near infrared on a planetary scale, Atmos. Chem. Phys. Discuss., 6, 9151-9185, 2006,

http://www.atmos-chem-phys-discuss.net/6/9151/2006/.

Haywood, J. M. and Shine, K. P.: Multi-spectral calculations of the radiative forcing of tropospheric sulphate and soot aerosols using a column model, Q. J. R. Meteorol. Soc., 123, 1907-1930, 1997.

Haywood, J. M. and Ramaswamy, V.: Global sensitivity studies of the direct radiative forcing due to anthropogenic sulfate and black carbon aerosols, J. Geophys. Res., 103, 6043-6058, 1998.

Hu, R.-M., Blanchet, J.-P., and Girard, E.: Evaluation of the direct and indirect radiative and climate effects of aerosols over the western Arctic, J. Geophys. Res., 110, D11213, doi:10.1029/2004JD005043, 2005.

Hess, M., Koepke, P., and Schult, I.: Optical properties of aerosols and clouds: The software package OPAC, Bull. Am. Meteorol. Soc., 79, 831-844, 1998.

Intergovernmental Panel on Climate Change (IPCC): Climate Change 2001, The Scientific Basis, edited by: Houghton J. T., Ding, Y., Griggs, D. J., et al., Cambridge Univ. Press, New York, 881 pp., 2001.

Jacobson, M. Z.: Global direct radiative forcing due to multicompo- nent anthropogenic and natural aerosols, J. Geophys. Res., 106, 1551-1568, 2001.

Joseph, J. H., Wiscombe, W. J., and Weinmann, J. A.: The DeltaEddington approximation of radiative flux transfer, J. Atmos. Sci., 33, 2452-2459, 1976.

Kaufman, Y. J., Tanré, D., Dubovik, O., Karnieli, A., and Remer, L. A.: Absorption of sunlight by dust as inferred from satellite and ground-based measurements, Geophys. Res. Lett., 28, 14791482, 2001.

Kaufman, Y. J., Tanré, D., and Boucher, O.: A satellite view of aerosols in the climate system, Nature, 419, 215-223, 2002.

Keil, A. and Haywood, J.: Solar radiative forcing by biomass burning aerosol particles during SAFARI-2000: A case study based on measured aerosol and cloud properties, J. Geophys. Res., 108(D13), 8467, doi:10.1029/2002JD002315, 2003.

King, M. D., Kaufmann, Y. J., Tanré, D., and Nakajima, T.: Remote sensing of tropospheric aerosols from space: Past, present, and future, Bull. Am. Meteorol. Sos., 80, 2229-2259, 1999.

Kinne, S., Lohmann, U., Feichter, J., Schulz, M., et al.: Monthly averages of aerosol properties: A global comparison among models, satellite data, and AERONET ground data, J. Geophys. Res., 108(D20), 4634, doi:10.1029/2001JD001253, 2003.

Kinne, S., Schulz, M., Textor, C., Guibert, S., et al.: An AeroCom initial assessment - optical properties in aerosol component modules of global models, Atmos. Chem. Phys., 6, 1815-1834, 2006, http://www.atmos-chem-phys.net/6/1815/2006/.

Koch D. and Hansen, J.: Distant origins of Arctic black carbon: A Goddard Institute for Space Studies ModelE experiment, J. Geophys. Res., 110, D04204, doi:10.1029/2004JD005296, 2005.

Koepke, P., Hess, M., Schult, I., and Shettle, E. P.: Global aerosol data set, Rep. No. 243, Max-Planck Institut für Meteorologie, Hamburg, Germany, 44 pp., 1997.

Kristjánsson, J. E., Iversen, T., Kirkevåg A., Seland, Ø., and Debernard, J.: Response of the climate system to aerosol direct and indirect forcing: Role of cloud feedbacks, J. Geophys. Res., 110, D24206, doi:10.1029/2005JD006299, 2005.

Lau, K. M., Kim, M. K., and Kim, K. M.: Asian summer monsoon anomalies induced by direct forcing: The role of the Tibetan plateau, Clim. Dyn., 26, 855-864, 2006.

Liao, H., Seinfeld, J. H., Adams, P. J., and Mickley, L. J.: Global radiative forcing of coupled tropospheric ozone and aerosols in a unified general circulation model, J. Geophys. Res., 109, D16207, doi:10.1029/2003JD004456, 2004.

Liu, H., Westphal, D., Wang, S., Shimizu, A., Sugimoto, N., Zhou, J., and Chen, Y.: A high-resolution numerical study of the Asian dust storms of April 2001, J. Geophys. Res., 108(D23), 8653, doi:10.1029/2002JD003178, 2003.

Loeb, N. G. and Manalo-Smith, N.: Top-of-atmosphere direct radiative effect of aerosols over global oceans from merged CERES and MODIS observations, J. Climate, 18, 3506-3526, 2005.

Marshall, S. F., Covert, D. S., and Charlson, R. J.: Relationship between asymmetry parameter and hemispheric backscatter ratio: Implications for climate forcing by aerosols, Appl. Opt., 34, 6306-6311, 1995.

Morcrette, J.-J.: The surface downward longwave radiation in the ECMWF forecast system, J. Climate, 15, 1875-1992, 2002.

Moulin, C. and Chiapello, I.: Evidence of the control of summer atmospheric transport of African dust over the Atlantic by Sahel sources from TOMS satellites (1979-2000), Geophys. Res. Lett., 
31, L02107, doi:10.1029/2003GL018931, 2004.

Nishizawa, T., Asano, S., Uchiyama, A., and Yamazaki, A.: Seasonal variation of aerosol direct radiative forcing and optical properties estimated from ground-based solar radiation measurements, J. Atmos. Sci., 61, 57-72, doi:10.1175/15200469(2004)061, 2004.

Penner, J. E., Chuang, C. C., and Grant, K.: Climate forcing by carbonaceous and sulfate aerosols, Clim. Dyn., 14, 839-851, 1998.

Podgorny I. A. and Ramanathan, V.: A modeling study of the direct effect of aerosols over the tropical Indian Ocean, J. Geophys. Res., 106, 24 097-24 105, 2001.

Ramanathan, V., Crutzen, P. J., Kiehl, J. T., and Rosenfeld, D.: Aerosols, climate, and the hydrological cycle, Science, 294, 2119-2124, 2001.

Redemann, J., Pilewskie, P., Russell, P. B., Livingston, J. M., Howard, S., Schmidt, B., Pommier, J., Gore, W., Eilers, J., and Wendisch, M.: Airborne measurements of spectral direct aerosol radiative forcing in the Intercontinental chemical Transport Experiment/Intercontinental Transport and Chemical Transformation of anthropogenic pollution, 2004, J. Geophys. Res., 111, D14210, doi:10.1029/2005JD006812, 2006.

Reddy, M. S., Boucher, O., Bellouin, N., Schulz, M., Balkanski, Y., Dufresne, J.-L., and Pham, M.: Estimates of global multicomponent aerosol optical depth and direct radiative perturbation in the Laboratoire de Météorologie Dynamique general circulation model, J. Geophys. Res., 110, D10S16, doi:10.1029/2004JD004757, 2005.

Remer, L. A. and Kaufman, Y. J.: Aerosol direct radiative effect at the top of the atmosphere over cloud free ocean derived from four years of MODIS data, Atmos. Chem. Phys., 6, 237-253, 2006, http://www.atmos-chem-phys.net/6/237/2006/.

Rignot, E. P. and Kanagaratnam, P.: Changes in the Velocity Structure of the Greenland Ice Sheet, Science, 311, 5763, doi:10.1126/science.1121381, 986-990, 2006.

Rossow, W. B. and Schiffer, R. A.: Advances in understanding clouds from ISCCP, Bull. Am. Meteorol. Soc., 80, 2261-2287, 1999.

Rossow, W. B., Walker, A. W., Beuschel, D. E., and Roiter, M. D.: International Satellite Cloud Climatology Project (ISCCP), Documentation of new cloud datasets, Wold Meteorol. Org. Geneva, 115 pp., 1996.

Shettle, E. P. and Weinmann, J. A.: The transfer of solar irradiance through inhomogeneous turbid atmospheres evaluated by Eddington's approximation, J. Atmos. Sci., 27, 1048-1055, 1970.

Schulz, C., Textor, C., Kinne, S., Balkanski, Y., et al.: Radiative forcing by aerosols as derived from the AeroCom present-day and pre-industrial simulations, Atmos. Chem. Phys., 6, 52255246, 2006,

http://www.atmos-chem-phys.net/6/5225/2006/.

Stackhouse, P. W., Gupta, S. K., Cox, S. J., Mikowitz, C., and Chiacchio, M.: New results from the NASA/GEWEX Surface Radiation Budget project: Evaluating El Nino effects at different scales, 11th American Meteorological Society Conference on Atmospheric Radiation, Ogden, UT, USA, P.3.6, 2002.

Sun, J., Zhang, M., and Liu, T.: Spatial and temporal characteristics of dust storms in China and its surrounding regions, 19601999: Relations to source area and climate, J. Geophys. Res., 106(D10), 10325-10333, 2001.

Takemura, T., Nakajima, H. T., Dubovik, O., Holben, B. N., and
Kinne, S.: Single-scattering albedo and radiative forcing of various aerosol species with a global three-dimensional model, J. Climate, 15, 333-352, 2002.

Takemura, T., Nakajima, T., Dubovik, O., Holben, B. N., and Kinne, S.: Single-scattering albedo and radiative forcing of various aerosol species with a global three-dimensional model, J. Climate, 15, 333-352, 2005.

Tanré, D., Haywood, J., Pelon, J., Léon, J. F, Chatenet, B., Formenti, P., Francis, P., Goloub, P., Highwood, E. J., and Myhre, G.: Measurement and modelling of the Saharan dust radiative impact: Overview of the Saharan Dust Experiment (SHADE), J. Geophys. Res., 108(D18), 8574, doi:10.1029/2002JD003273, 2003.

Textor, C., Schulz, M., Guibert, S., Kinne, S., et al.: Analysis and quantification of the diversities of aerosol life cycles within AeroCom, Atmos. Chem. Phys., 6, 1777-1813, 2006, http://www.atmos-chem-phys.net/6/1777/2006/.

Thekaekara, M. P. and Drummond, A. J.: Standard values for the solar constant and its spectral components, Nature Phys. Sci., 229, 6-9, 1971.

Torres, O., Bhartia, P. K., Herman, J. R., Sinyuk A., and Holben, B.: A long term record of aerosol optical thickness from TOMS observations and comparison to AERONET measurements, J. Atmos. Sci., 59, 398-413, 2002.

Treffeisen, R., Rinke, A., Fortmann, M., Dethloff, K., Herber, A., and Yamanouchi, T.: A case study of the radiative effects of arctic aerosols in March 2000, Atmos. Environ, 39, 899-911, 2005.

Vardavas, I. and Carver, J. H.: Solar and terrestrial parameterizations for radiative convective models, Planet. Space Sci., 32, 1307-1325, 1984.

Wei, X. and co-authors: Comparison of albedos computed by land surface models and evaluation against remotely sensed data, J. Geophys. Res., 106, 20 687-20 702, 2001.

Willson, R. C.: Total solar irradiance trend during solar cycles 21 and 22, Science, 277, 1963-1965, 1997.

Yamanouchi T, Treffeisen R., Herber A., Shiobara M., Yamagata S., Hara K., Sato K., Yabuki M., Tomikawa Y., Rinke A., Neuber R., Schumachter R., Kriews M., Strom J., Schrems O., and Gernandt H.: Arctic Study of Tropospheric Aerosol and Radiation (ASTAR) 2000: Arctic haze case study, Tellus, 57B, 141-152, 2005.

Yu, H., Dickinson, R. E., Chin, M., Kaufman, Y. J., Zhou, M., Zhou, L., Tian, Y., Dubovik, O., and Holben, B. N.: The direct radiative effect of aerosols as determined from a combination of MODIS retrievals and GOCART simulations, J. Geophys. Res., 109, D03206, doi:10.1029/2003JD003914, 2004.

Yu, H., Kaufman, Y. J., Chin, M., Feingold, G., Remer, L. A., Anderson, T. L., Balkanski, Y., Bellouin, N., Boucher, O., Christopher, S., DeCola, P., Kahn, R., Koch, D., Loeb, N., Reddy, M. S., Schulz, M., Takemura, T., and Zhou, M.: A review of measurement-based assessment of aerosol direct radiative effect and forcing, Atmos. Chem. Phys., 6, 613-666, 2006, http://www.atmos-chem-phys.net/6/613/2006/.

Zhang, J., Christopher, S. A., Remer, L. A., and Kaufman, Y. J.: Shortwave aerosol cloud-free radiative forcing from Terra, II: Global and seasonal distributions, J. Geophys. Res., D10S24, doi:10.1029/2004JD005009, 2005.

Zhang, Y., Rossow, W. B., and Stackhouse Jr., P. W.: Comparison of different global information sources used in surface radiative flux 
calculation: Radiative properties of the near-surface atmosphere, J. Geophys. Res., 111, D13106, doi:10.1029/2005JD006873, 2006.

Zhao, T. X.-P., Laszlo, I., Minnis, P., and Remer, L.: Comparison and analysis of two aerosol retrievals over the ocean in the Terra/Clouds and the Earth's Radiant Energy System-Moderate Resolution Imaging Spectroradiometer single scanner footprint data: 1. Global evaluation, J. Geophys. Res., 110, D21208, doi:10.1029/2005JD005851, 2005.
Zhou, M., Yu, H., Dickinson, R. E., Dubovik, O., and Holben, B. N.: A normalized description of the direct effect of key aerosol types on solar radiation as estimated from Aerosol Robotic Network aerosols and Moderate Resolution Imaging Spectroradiometer albedos, J. Geophys. Res., 110, D19202, doi:10.1029/2005JD005909, 2005. 